\title{
On the Relationship between EFL Learners' Grammar Learning Strategy Use and Their Grammar Performance: Learners' Gender in Focus
}

\author{
Fereshteh Azizmohammadi \\ Department of English Language and Literature, Ayatollah Amoli Branch, Islamic Azad University, Amol, Iran \\ Hamed Barjesteh \\ Department of English Language and Literature, Ayatollah Amoli Branch, Islamic Azad University, Amol, Iran
}

\begin{abstract}
This study sought to investigate the interplay between grammar strategies employed by intermediate EFL learner and their performance on a grammar test. To undertake the study, eighty homogenized intermediate students, comprising 37 males and 29 females, took part in the study. Having been homogenized via quick placement test (QPT), the participants were asked to respond to Oxford's (1990) grammar learning strategies questionnaire (hereafter, GLSQ). Next, the participants were asked to take a grammar test. The findings revealed a significant relationship among six subscales of GLSs and EFL learners' performance on the grammar test. In addition, the results indicated a significant difference between male and female students in term of their performance on the grammar test. More precisely, female students outperformed the male counterpart as far as their performance on grammar test was concerned. In addition, the results attested that cognitive strategy and compensation learning strategy were the most and the least strategy types employed by the participants. The findings have pedagogical implication for both English as a foreign or second language.
\end{abstract}

Index Terms - gender, grammar, grammar performance, language learning strategies

\section{INTRODUCTION}

Recently, the focus of teacher-oriented standpoint has yielded to leaner-centered perspective. New learning strategies are presented to the learners to extend their own personal achievements in language learning process. Learning strategies are comprised of mental processes- thoughts or behaviors- which help learners perceive, learn, or maintain new information. The concept of learning strategies plays a crucial role in second or foreign language learning studies. Although a great number of studies have been conducted to put learning strategies in practice, the idea of learning strategies is still unclear.

Dörnyei (2005) also claim that the theory behind the learning strategies has not been dealt with in a critical manner since the concepts and definitions have been contradictory up to now. Learning strategies are "operations or steps used by a learner to facilitate the acquisition, storage, retrieval or use of information" (Aslan, 2009, p.99).Successful target language learners are enthusiastic guessers, enjoying from a motif to start out communication, are not nervous to make errors, bind attention to forms on the basis of analogy and analysis, focus on meaning and take advantage of chances to develop something and continue controlling the other's speech (Rubin, 1975).

Brumfit and Johnson (1987) stated that although language learners are presented with formal English teaching for many years in developing countries, they lack enough communication abilities to use language in real contexts either in spoken or written language. Most scholars (Anderson, 2005; Chamot, 2004; Ehrman, Leaver \& Oxford, 2003; Oxford, 1990; 2003; Rubin, 1975) believe that the problem is lack of effective use of grammar learning strategies in the long run.

Also, there is a deficiency in research on using grammar learning strategies by students since grammar has a crucial role in almost all educational activities. By acquiring grammar knowledge, learners are able to understand how to use words to make complex meanings and specific literary effects help them to be more efficient readers. As Cornwall (2010) mentions, if learners acquire sufficient grammatical knowledge, they will be able to write more systematically.

Oxford (1990) claimed that there was a lack of enough research on the social/affective strategies. He identified the reasons and added that learners have not been accustomed to focus their attention on their own feelings and social behaviors during the target language processing. O'Malley and Chamot (1990) claimed that cognitive (translating and analyzing) and metacognitive (planning and organizing) strategies often cooperate with each other and follow one another since applying two kinds of strategies are often more effective than one single strategy. 
If learners do not have a deep and good knowledge of grammar, they will certainly commit many mistakes in writing or speaking. The knowledge of grammar for foreign learners is the main framework to construct sentences which can be used for communication in English. Therefore, if the students do not know how to make and build sentence, they will not be able to communicate well in English. Additionally, knowing grammar is very essential because it is a way of attaining linguistic accuracy; the more correctly and accurately a message is conveyed, the lesser the chances for misapprehension and misunderstanding in communication. If there is no grammatical competence, communicators do not take part willingly and completely and communication tends to be failure. There are some factors which could affect language learning strategies by learners. According to some researchers, different variables such as age, gender, language proficiency, motivation, anxiety, aptitude and cultural background affect using language learning strategies by students (Ahmadi \& Mahmoodi, 2012; Aslan, 2009; Ghavamnia, Kassaian\&Dabaghi, 2011; Gurata, 2008; Hong-Nam \&Leavell, 2006; Li, 2005; Rahimi, Riazi,\& Safi ,2008; Salahshour, Sharifi, \&Salahshour, 2013). However, this research intended to discover the impact of gender on using learning strategies.

It is worth mentioning that findings of this research could assist teachers to be aware of learners' strategies in learning grammar in addition to gender differences, help their students to be responsive to using learning strategies in their learning process, and create a satisfactory learning context for using learning strategies of both genders. Therefore, learners were able to become independent and feel responsibility for their own learning. The present study could also help solve the problems of EFL teachers and learners in decreasing the amount of affective factors and increasing the level of cognitive and meta-cognitive abilities. The outcomes could inform instructors that helping learners enhance their level of analysis and monitoring will be of great significance in learning.

There has been a controversy on the role of grammar as an important issue in the foreign language learning for a long time. The role of grammar in teaching approaches has been discussed by a number of linguistic theories and methodologies in the history of language teaching. The way grammar has been considered has a direct impact on learning processes and different aspects in foreign language teaching (Nassaji \& Fotos, 2011; Pontarolo, 2013; Rama \& Agullo, 2012). Grammar is one of the language aspects that learners may not have a command on and is considered as difficult to learn and requires some techniques to use. "Since grammar is complex, and students' learning styles vary, learning grammar is not likely to be accomplished through a single means." (Larsen-Freeman, 2001, p. 40). This also applies to Cornwall (2010) who identified that if learners are prepared with adequate grammatical knowledge, they will be able to write with the correct grammar of the language. In addition, Pagcaliwagan (2016) asserts that teaching grammar to students is essential because it equips them with deep understanding and proficiency in the language. It also directs and helps them understand. For instance, students will know how sentences are constructed, how to select vocabulary used and the types of words that encompass a sentence. In fact, without grammar even messages could be decoded wrongly and meaning is behind due to the important role that grammar plays in one's language. In language teaching, grammar has given different states in a variety of methodologies and approaches. Three general instructional approaches can be considered for these situations, beginning with those that perceived teaching in terms of methods with a complete emphasis on grammar, continuing later as presentation of meaningful communication, and more recently a set of instructional choices with a focus on both meaning and grammar has been come up (Nassaji \& Fotos, 2011; Richards \& Rodgers, 2001).

Long time ago, grammar had an important issue in language teaching because it was believed that knowing the structure of the language improves learners' intellectual capability and the right production of the language spontaneously. However, traditional methods depend on the limited use of grammar were criticized by many researchers due to the learners' inability to use the language communicatively. So, new approaches that promoted meaningful communication became known (Hinkel \& Fotos, 2002; Nassaji \& Fotos, 2011; Richards \& Rodgers, 2001). There is not a formal grammar teaching in communicative approaches and it has a restricted role due to the fact that learners would obtain the forms and vocabulary naturally when comprehending and responding to the input (Hinkel\&Fotos, 2002). In general, the importance of grammar has been reviewed in second language acquisition research. Many researchers now believe that teaching grammar should be considered in second language classrooms. According to Nassaji and Fotos (2011), language teaching professionals are informed of the crucial role of grammar in language teaching and learning. Schmidt (1990) claims that some reasons for reconsideration of the role of grammar are first, in language learning it is proved that some degree of consciousness is essential. Otherwise, it leads to some problems in learning a language. Furthermore, there is enough empirical evidence that teaching approaches with no focus on grammar and the only emphasis on meaning are inadequate (Nassaji \& Fotos, 2011).

According to some scholars such as Krashen (1981, 1982) and Krashen and Terrell (1983), grammar has an important role in language teaching. In addition, he presented an adequate support for communicative language teaching by his model of second language learning and the difference he made between acquisitions and teaching (Richards $\&$ Rodgers, 2001). Krashen (1981) believes that learners should be exposed to comprehensible input in order to "acquire" language unconsciously rather than "learn" it consciously by means of teaching of grammatical rules explicitly.

On the contrary, many researchers have attempted to reinstate the role of grammar. As grammatical competence is one of the constituents of communicative competence, Ellis (2006) states that learning based on instruction may need achieving an advanced level of grammatical competence and performance. He claims that learners' proficiency is affected by teaching different grammatical structures in meaningful context. Furthermore, Hinkel and Fotos (2002) state 
that instructed grammar learning can be regarded as communicative input, based on which learners can internalize grammar rules. This issue is of paramount importance especially for the EFL situation, in which there is a lack of communicative exposure to the target language. Lightbown and Spada (2006) also support the important role of grammar in language learning. They are assured that by mere emphasis on comprehensible input and communication, language acquisition is not achieved automatically. Furthermore, as Debata (2013) mentions grammar is essential to assist students in the correction of mistakes and enhancement of written work.

Different practitioners attested that students can take the advantage of learning strategies in order to foster their grammatical competence. Learning strategies have achieved significant importance in teaching-learning context and they are the center of attention. Some language theorists have explained language learning strategies in different ways. Rubin (1975) explains learning strategies as "the techniques or devise which a learner may use to acquire knowledge" (p.43). According to O'Malley and Chamot (1990), learning strategies are "the special thoughts or behaviors that individuals use to help them comprehend, learn, or retain new information" (p.1). Therefore, learning strategies were considered as specific ways of processing information that improve comprehension, learning, or retention of the information. As Brown (2007) on the other hand states that learning strategies are connected with "input- to processing, storage, and retrieval, that is, to taking messages from others" (p.132). Moreover, Paterson and Rosbottom (1995) point out that learning strategies are "the particular habits or patterns espoused when engaged in the learning process" (p.15). Grammar learning strategies were explained by Ozmen and Gulleroglu (2013) as “... actions and thoughts that learners consciously employ to make language learning and/ or language use easier, more effective, more efficient, and more enjoyable" (p.354). Similar to all other types of strategic behaviors, grammar learning strategies have distinguishing features which are outlined by Griffiths (2008) as cited in Pawlak (2009). These are: (1) they are actions to be taken by the learner; (2) Their employment is at least partially conscious; (3) They are elective means learners choose; (4) Their use involves goal-oriented, purposeful activity, and (5) They are used to regulate, facilitate, and control the learning process. According to Oxford (1990) learning strategies are divided into two types: direct and indirect strategies. Direct strategies can be categorized into: memory, cognitive, and compensation. Memory strategies include the ability to arrange items in order, create mental linkages and reviewing. Memory strategies "aid in entering information into longterm memory and retrieving information when needed for communication." (Oxford, 1990, p. 71). On the other hand, indirect strategies involve metacognitive, affective and social strategies. Furthermore, O’Malley and Chamot (1990) classified language learning strategies into cognitive, meta- cognitive and social strategies. Cognitive strategies deal directly with the information received and the use of these information to improve learning. Cognitive strategies comprise conscious actions which the language learners take to handle the received information such as taking notes, using resources and forming and organizing information. Meta-cognitive strategies entail language learners to make plans such as planning their own learning, observing their own speech and being able to evaluate their success of a definite strategy. The third type of learning strategies is social strategies in which learners socially interact with other people to learn the language. Concerning research on the investigation of grammar learning strategies, Fazeli's (2011) conducted a study to explore English grammar skills learning strategies by students of Jimma University. It is proved that the students' perception of the use of grammar learning strategies differs from their actual usage. The finding of the questionnaire indicates that all the six strategies were employed by respondents. But according to the findings of the think aloud technique, students use only three (Cognitive, Compensation, and Memory) strategies of the six strategies. Despite learners were aware of the use of learning strategies, some of them did not have any information regarding their use. Furthermore, in a research by Mystkowska-Wiertelak (2008) on the use of grammar learning strategies of Polish secondary school students findings indicate that the students use all the six strategies. In the study, in order to initiate and keep up communication with the native speakers many students use modern technology apart from using traditional teaching aids such as dictionaries and grammar books.

In another study on the use of grammar learning strategies and student attainment of English preparatory classes in Turkish by Yalcin (2005), it was showed that there was no significant relationship between learners' achievement and their grammar leaning strategy use. In addition, a study conducted by Pawlak (2009) on the relationship between grammar learning strategies and language achievement of English students, it was also failed to find a positive relationship between the use of grammar learning strategies and language attainment. Saricoban (2005) investigated the strategies employed by Turkish EFL learners in learning English grammar. Questionnaire was used to explore which grammar learning strategies used by those students. The learning strategies were classified into cognitive, metacognitive, and social-affective strategies. The results of the study revealed that Turkish students unconsciously used the cognitive strategies and these learners needed to use socio-affective strategies to study and learn grammar competently. In addition, Gimeno (2002) conducted an experimental research based on O'Mally and Chamot's classification of learning strategies. The study aimed to investigate the efficiency of teaching students the use of cognitive and metacognitive learning strategies in learning grammar. The findings of the study reported that the experimental group which used cognitive and meta-cognitive strategies achieved a great improvement in comprehending the rules of grammar than the control group did. The researcher inferred that teaching students how to use learning strategies can assist them develop their language proficiency and motivate them to be more independent learners. While previous explanations of learning strategies focused on products of learning and behaviors which indicated hidden cognitive processes, as well as restricting learning strategies to receptive skills, in the end descriptions presented an unambiguous understanding of 
what learners think and do during language learning. In this respect, Cohen (1996) describes learning strategies as "the steps or actions selected by learners either to improve the learning of a second language, the use of it, or both" (p.2). Likewise, according to Chamot (2004), learning strategies are "the conscious thoughts and actions that learners take in order to achieve a learning goal” (p.14). Major characteristics of language learning strategies are listed by Oxford (1990) in which language learning strategies:

1. provide the main goal of communicative competence. In order to improve communicative competence, it is vital for learners to develop: knowledge of grammatical rules (grammatical competence), the capacity to use the language properly in specific social context in which the communication occurs (sociolinguistics competence), the ability to understand messages logically with the whole text (discourse competence) and the capability to start, manipulate, and redirect communication (strategic competence) Canale and Swain (1980),

2. motivate learners for more self-direction,

3. improve the role of teachers. The roles of teachers involve recognizing, learning strategies which are used by learners, organizing training on learning strategies and assisting learners to become self-reliant,

4. are problem oriented which are used as instruments to resolve a problem or to perform a task,

5. are certain actions taken by the learners in order to improve their learning,

6. include learners' features, not just the cognitive; those related to the mental processing and dealing with the new language. Rather they consist of metacognitive functions like planning, evaluation and accomplishing one's own learning; emotional, social, and other functions as well,

7. offer direct and indirect support of learning,

8. are visible to some degree. They are not always easily obvious. For example, to make mental associations, which is memory strategy, cannot be observed. But, doing works in collaboration with others can be observed,

9. have some degrees of consciousness. They usually represent conscious attempts by learners to manipulate their learning,

10. can be acquired through teaching,

11. are adaptable which means that they do not always have the same successions or specific patterns, and

12. affected by various factors to be selected and applied by the learner such as motivation, gender, nationality, age, learning style, etc.

One of the most practical explanations of language learning strategies was presented by Oxford (1990). She stated that language learning strategies are "the specific actions taken by the learner to make learning easier, faster, more enjoyable, more self-directed, more effective and more transferable to new situations" (p.8). Concerning the features of learning strategies, Oxford (1990) claimed that they motivate learners for more self-direction, improve the role of teachers. The roles of teachers involve recognizing, and offer direct and indirect support of learning. O'Malley and Chamot (1990) identified three main strategy classifications. These are cognitive, metacognitive, and social/affective strategies. Cognitive strategies are directly related to the performance of information processing (e.g., translation, note taking, repetition). Metacognitive strategies try to manage language learning (e.g., planning, monitoring, and selfevaluation). Social/affective strategies are linked to communications with others in leaning (e.g., cooperation, asking for the clarification of questions). Oxford (1990) presented a comprehensive classification system of language learning strategies using the two main groups suggested by Rubin's (1975) model; direct and indirect strategies. Due to the fact that Oxford's classification of language learning strategies taxonomy is comprehensive, systematic, and detailed and that the strategies are easier to apply to most language skills in different leaning contexts this study employed this classification. Moreover, Oxford (1990) claimed that cognitive strategies empower learners to control grammatical rules by utilizing the grammar rule meaningfully such as identifying and using an integration of rules in sentences repeatedly, and employing the new pattern in a real context such as listening to a lecture, reading a book or article, or writing a letter in the new grammar structure. Learners also can implement grammar structures by saying or writing them several times, listen to them many times, practicing, and emulating a native speaker.

According to Oxford (2003), metacognitive strategies are compulsory for successful language learning. These strategies are utilized for emphasizing learning by paying attention to particular grammar tasks or activities such as, paying attention to the rules from reference books. Through such strategies, the learners are able to analyze a concept or principle and connect it with their previous knowledge. Affective strategies assist learners to be able to manipulate and manage personal emotions, attitudes, and values; which are the essential components for successful language learning (Oxford, 1990; 2003). To be aware of how to manipulate individual's emotions and viewpoints may affect grammar learning process positively since it makes the learning more pleasant and successful. In addition, it is also believed that negative emotions obstruct improvement. Successful language learners are often able to control their viewpoints and feelings while learning grammar. Actions which are taken by learners so as to look for support or to have communication with other learners or more professional speakers of the language are social strategies (Oxford, 1990; 2003). Interaction among people is required to learn language successfully and productively since language is a form of social behavior. So that learners should improve cooperation with others. As a result, they will have the opportunity to learn from their peers. For example, if learners practice different grammar activities in groups, it may be possible that less successful learners gain those strategies which are used by successful learners. Furthermore, correct grammatical forms can be provided to learners by asking questions and/or explanations for the intricate issues they tackle with from 
their more proficient friends, native speakers, or teachers. Additionally, social strategies improve learners' capability to understand people's emotions and feelings and enhance cultural understanding. Few studies had been carried on to compare the learning strategies of cognitive, meta-cognitive and social/affective, memory- related strategies with grammatical knowledge. This study attempted to find out if there are any relationships between learners' grammar learning strategies and their grammar performance. This study intended to investigate the relationship between all learning strategies and learners' grammar performance among intermediate EFL learners. To address the gap, this study intends to probe the interplay between EFL Learners' GLSs and their performance on a grammar test. Accordingly, the following research questions were addressed:

RQ1. Is there any significant relationship between cognitive learning strategies and intermediate EFL learners' grammar performance?

RQ2. Is there any significant relationship between meta-cognitive learning strategies and intermediate EFL learners' grammar performance?

RQ3. Is there any significant relationship between social learning strategies and intermediate EFL learners' grammar performance?

RQ4. Is there any significant relationship between affective learning strategies and intermediate EFL learners' grammar performance?

RQ5. Is there a significant difference between learners' learning strategies and grammar performance with respect to gender?

\section{Methodology}

\section{Participants}

A total of $80 \mathrm{EFL}$ students were selected as the target subject of the present study. A convenience sampling procedure was adopted for the selection of the participants. They were all intermediate EFL students who were classified at intermediate language proficiency level as far as the placement test of the language institute was concerned. They were all enrolled in Mehr English language institute in Tehran, Iran. All participants were native speaker of Persian who had similar experience in learning English language at different language institutes. Approximately, they had experience in learning English language from three to four years. There were both male $(\mathrm{N}=37)$ and female $(\mathrm{N}=29)$ learners. Their age ranged from 20 to 35 years old $(M=26.59)$.

\section{Instruments}

There were three main instruments used for the purpose of this study.

To ensure the homogeneity of the participants and their ability to understand and complete the English version of the questionnaire, the Quick Placement Test (QPT) was administered in order to select intermediate learners. The score was out of 60. To meet the aforementioned purposes, initially, a language proficiency test version 2, including 60 items (i.e., matching, cloze passages, and multiple choice questions) was administered to ensure the homogeneity of the learners. The test items mainly focused on reading skill, grammar, and vocabulary. The participants were given 30 minutes to answer them. Those learners receiving 30-39 scores out of 60 were considered as intermediate ones. The reliability of the test was estimated through Cronbach Alpha and found to be 0.87 which indicated a high reliability.

Also, in order to gather valuable information from data sources, Oxford's (1990) ESL/EFL Strategy Inventory for Language Learners (SILL) was adapted. The SILL had been employed as a key instrument in numerous studies assessing the frequency of strategy use by students from different linguistic and cultural backgrounds. Therefore, the SILL was modified as it was convenient to explore the learners' grammar learning strategies. This modified Grammar Learning Strategies Questionnaires (GLSQ) consisted of 35 statements grouped under the six categories as proposed by Oxford (1990). Part one comprised seven statements concerned to memory strategies. Part two involved eight statements about cognitive strategies. Part three consisted of three statements on compensation strategies. Part four contained eight statements about metacognitive strategies. Part five included five statements about affective strategies, and part six consisted of four statements on Social Strategies. The participants were required to respond on a five- point Likert Scale, ranging from 1 (Never or almost never true of me) to 5 (always or almost always true of me). The participants had about 20-25 minutes to finish. It is based on a five-point Likert scale. The calculated Cronbach alpha revealed an acceptable reliability (0.92).

Regarding the grammar performance, in order to measure the grammar performance of the participants, they were asked to sit for a grammar quiz. A highly standard test of PBT structure test was administrated to all intermediate level students. This test included 40 questions. The test's reliability was estimated through Cronbach Alpha and found to be 0.86 which showed a high reliability. As a note of caution, the validity of all the instruments were accounted for by discussing the contents and the statements with at least three EFL experts and alterations were made according to their feedbacks and comments.

\section{Procedures}

To obtain reasonable answers to the research questions mentioned earlier, the following steps were taken: First, QPT was distributed among EFL students of Iran Mehr Institute to determine the homogeneity of the participants and select intermediate language learners. Total score was 60. After conducting and analyzing the placement test, those students receiving the scores from 30 to 39 were selected. Second, Oxford's (1990) Grammar Learning Strategies Questionnaire 
(GLSQ) was administered to the selected intermediate learners. It was a 35-item questionnaire, a 5-point Likert scale ranging from 1 (Never or almost never true of me) to 5 (always or almost always true of me).Afterwards, the participants were requested to sit for a grammar quiz. This quiz was based on NTC TOEFL PBT structure test including 40 questions

\section{Data Analysis}

A correlational study was adopted to probe the interplay among the variables of the current study. A correlational design is a non-experimental study which seeks to investigate the interrelationships among variables, and to uncover how the variables are related. To comply with the objective of the current study, this paper seeks to figure out the probable relationships among cognitive, meta-cognitive, social, and affective learning strategies, as well as intermediate EFL learners' grammar performance in terms of gender. In so doing, the basic assumption for the correlational study were employed. Accordingly, Pearson product moment correlation was conducted to probe the interrelationships among the targeted variables.

\section{RESUlts AND ANALYSIS}

\section{Analysis of Research Question One}

The researcher conducted a series of calculations and statistical analysis in order to test the raised hypotheses. In this phase, Pearson correlations analysis was run. As indicated in the Table $1(\mathrm{r}(64)=0.00, p<.05)$. This value represents a large effect size. Table 1 indicates that there is a significantly relationship between cognitive learning strategies and learners' grammar performances. Thus, the null-hypothesis was rejected.

TABLE 1

PEARson Correlation Of COGNITIVE Strategies AND Grammar PERFormance

\begin{tabular}{lll}
\multicolumn{2}{c}{ PEARSON CORRELATION OF COGNITIVE STRATEGIES AND GRAMMAR PERFORMANCE } \\
\hline & & Grammar Performance \\
\hline \multirow{3}{*}{ Cognitive Strategies } & Pearson Correlation & 0.69 \\
& Sig. (2-tailed) & 0.00 \\
& N1 & 66 \\
\hline
\end{tabular}

\section{Analysis of Research Question Two}

In this section, the correlation of meta-cognitive strategies and grammar performance is investigated. According to Table $2,\left(\mathrm{r}_{(64)}=0.73, p<.05\right.$ representing a large effect size $)$ it can be concluded that there was a significantly positive and large correlation between meta-cognitive learning strategies and learners' grammar performances. So, the nullhypothesis was rejected.

TABLE 2

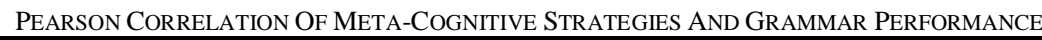

\begin{tabular}{lll}
\hline & & Grammar Performance \\
\hline \multirow{2}{*}{ Meta-cognitive } & Pearson Correlation & 0.73 \\
Strategies & Sig. (2-tailed) & 0.00 \\
& $\mathrm{~N}$ & 66 \\
\hline
\end{tabular}

\section{Analysis of Research Question Three}

There was another phase in this research on the correlation of social strategies and grammar performance of EFL learners. Based on the results displayed in Table $3(\mathrm{r}(64)=0.40, \mathrm{P}<.05$ representing a medium effect size), it can be concluded that there was a significantly positive correlation between social learning strategies and learners' grammar performances. Thus, the null-hypothesis was rejected.

TABLE 3

PEARSON CORRELATION OF SOCIAL STRATEGIES AND GRAMMAR PERFORMANCE

\begin{tabular}{lll}
\hline & & Grammar Performance \\
\hline \multirow{3}{*}{ Social Strategies } & Pearson Correlation & 0.40 \\
& Sig. (2-tailed) & 0.00 \\
& $\mathrm{~N}$ & 66 \\
\hline
\end{tabular}

\section{Analysis of Research Question Four}

In this part of the study, the correlation of the affective strategies and grammar performance of EFL learners was probed. Based on the results displayed in Table $4(\mathrm{r}(64)=0.54, \mathrm{P}<.05$ representing a medium effect size), it can be concluded that there was a significantly positive correlation between affective learning strategies and learners' grammar performances. Thus, the null-hypothesis was rejected.

TABLE 4

PEARSON CORRELATION OF AFFECTIVE STRATEGIES AND GRAMMAR PERFORMANCE

\begin{tabular}{lll}
\hline & & Grammar Performance \\
\hline \multirow{3}{*}{ Affective Strategies } & Pearson Correlation & 0.54 \\
& Sig. (2-tailed) & 0.000 \\
& $\mathrm{~N}$ & 66 \\
\hline
\end{tabular}




\section{Analysis of Research Question Five}

The last research hypothesis investigated the difference between learners' male and female learning strategies and their grammar performance. Table 5 reveals that there is a statistically significant difference between the two groups' means on their grammar performances $\left(t_{(64)}=2.17, p<.01\right)$. With regard to Table 5, female group $(M=30.49)$ outperformed the male counterpart group $(M=25.68)$ in the grammar performance.

TABLE 5

INDEPENDENT SAMPLES T-TEST; MALE AND FEMALE GRAMMAR PERFORMANCE

\begin{tabular}{|c|c|c|c|c|c|c|}
\hline \multirow[t]{2}{*}{ Variables } & \multicolumn{6}{|c|}{ Independent Samples t-test } \\
\hline & Groups & $\mathrm{N}$ & Mean & $\mathrm{T}$ & df & Sig \\
\hline \multirow{2}{*}{$\begin{array}{l}\text { Grammar } \\
\text { Performance }\end{array}$} & Female & 29 & 30.49 & \multirow[t]{2}{*}{2.17} & \multirow[t]{2}{*}{64} & \multirow[t]{2}{*}{0.033} \\
\hline & Male & 37 & 25.68 & & & \\
\hline
\end{tabular}

\section{DISCUSSION}

The major focus of this study was to explore learners' use of grammar learning strategies and to detect the relationship between grammar performance and EFL learners' grammar learning strategies. According the findings of this study, the most significant finding was that cognitive strategy was the most preferred strategy by learners. This is followed by meta-cognitive, social, and affective strategies. Regarding the metacognitive strategy, this was the second favorable strategy from both groups' points of view. This finding was not compatible with Oxford (1990), Hong-Nam and Leavell (2006), Rahimi, Riazi and Saif (2008), and Salahshouret al. (2013) who believed that females were superior to men with respect to metacognitive strategy.

Besides, learners utilized both direct (memory, cognitive, and compensation) strategies and indirect (metacognitive, affective, and social) strategies. This is not in line with the previous studies of Abdi and Daghir (2010) and Aslan (2009) which claimed that the participants were good at indirect strategies than direct strategies. The findings of the current research were not congruent with the finding of $\mathrm{Li}$ (2005) and Tam (2013) who reported that compensation strategies were the most preferred of all. However, it was proved that the findings were quite consistent with the findings of Abdi and Daghir (2010), Wen and Wang (2004), Zhang (2009), Wahyuni (2013), which revealed compensation strategies as the least frequently used ones.

These findings are in line with Hong-Nam and Leavell (2006), Ozmen and Gulleroglu (2013), Tam (2013), and Temesgen (2013) that reported affective strategies as one of the least preferred category. However, this study didn't confirm the findings of Ahmadi and Mahmoodi's (2012) which claimed affective strategies were the most used category by the learners. This negative tendency in the use of Affective strategies is perhaps due to the learners' low intention to notice their personal emotions, attitudes, and motivations while studying or learning grammar. Needless to mention that as Oxford (1990) believes, the affective side of the learner is probably one of the very biggest influences on language learning failure or success.

In line with Yalcin (2006), this study proved that there was statistically significant difference between males and females in the use of grammar learning strategies. In line with Oxford's (1990) report on cognitive strategies, this study proved that cognitive strategies are typically found to be the most popular strategies with language learners. Inconsistent with the finding of the previous research by Rahimi, Riazi, and Saif's (2008) study which revealed males superiority to females in the use of cognitive strategies, the findings of this study illustrated that both groups of males and females voted for this strategy similarly. However, this finding was quite inconsistent with the result Ahmadi and Mahmoodi (2012), which revealed that cognitive strategies were the least applied strategy categories by males and females. This study didn't confirm Salahshouret al. (2013) study revealing females were reported to use cognitive strategies more than males.

In line with Oxford's (1990) report on cognitive strategies, this study proved that cognitive strategies are typically found to be the most popular strategies with language learners. Inconsistent with the finding of the previous research by Rahimi, Riazi, and Saif's (2008) study which revealed males superiority to females in the use of cognitive strategies, the findings of this study illustrated that both groups of males and females voted for this strategy similarly. The findings reveal that the higher use of metacognitive strategies is, the more ambitious the students are to settle language learning. This is on the same route with Goh's (2008) that meta-cognitive strategies can potentially heighten learners' awareness of learning processes and develops learners' ability to use appropriate strategies to decode grammar intricacies. In addition, in line with Oller and Perkin (1978) claiming that affective factors determine how effectively one learns, this is also backed up by Dornyei (2005) who emphasized that social and affective factors play a pivotal role in the quality of learning. The same remark was made by Brown (2007) proposing that it is critical to attain a broad understanding of affect in language learning as the more attention is paid to these strategies, the more effectively is the learning fostered. The other finding of this research suggested that more focus must be put on learning strategies. This study also echoes Goh and Taib (2006) who claim that improving the strategies especially cognitive and meta-cognitive knowledge would motivate students to pick the best and the most appropriate strategies to augment their performances. The findings of this study portrayed that the students could perform much better if they boost their cognitive and 
metacognitive knowledge. This can help all Iranian English students who wish to be skilled in prefect performances in their grammar development.

In terms of affective strategies, the findings of this research also suggested that both genders did identically. This was against the previous findings (Aslan, 2009; Hong-Nam \& Leavell, 2006; Wahyuni, 2013; Zeynali, 2012) which concluded that females were superior to men with regards to affective strategies. Nevertheless, this finding is inconsistent with a study of Ahmadi and Mahmoodi (2012) that found affective strategies to be among the most used strategy categories. With respect to social strategies, in this study, both groups did similarly. This strategy was ranked fourth in both viewpoints. The findings of the present study is incongruent with the result of Radwan's (2011) research, which reported males use of social strategies more than females because of the cultural background of the students. Besides, the finding of the present study was not attuned with Hong-Nam and Leavell (2006), Tam (2013), Neuman (2007), and Zeynali (2012) in which female learners tend to use Social strategies more than male learners. In addition, metacognitive strategies proved to be the second top priority for both genders. Regarding the metacognitive strategy, this was the second favorable strategy from both groups' points of view. This finding was not compatible with Oxford (1990), Hong-Nam and Leavell (2006), Rahimi, Riazi and Saif (2008), and Salahshouret al. (2013) who believed that females were superior to men with respect to metacognitive strategy.

Gender differences, therefore, turned out to have no significant effect on participants overall use of grammar learning strategies, as both groups were reported to have similarity in all six strategy categories. This is in line with the former studies (Hong-Nam \& Leavell, 2006; Li, 2005; Nisbet, Tindall\& Arroyo, 2005; Radwan, 2011; Rahimi, Riazi\&Saif, 2008; Wahyuni, 2013), which have reported no significant difference between males and females in the use of overall learning strategies.

\section{CONCLUSION}

The present study made a rigorous and vigorous attempt to investigate how significantly grammar learning strategies could have parts in learners' learning in general and in their grammar performance in particular. The main aim of this research was to find any significant relationship between grammar learning strategies including cognitive, metacognitive, social, and affective strategies and grammar performances of intermediate EFL learners. Given the outcomes of this research, the study came up with the conclusion that all the learning strategies correlated significantly with grammar performances of the learners. In addition, results indicated that there was a statistically significant difference between the two groups' means on their grammar performances. It was concluded that there was a significant difference in using grammar learning strategies between males and females. Female group outperformed the male counterpart group in the grammar performance.

\section{REFERENCES}

[1] Abdi, R., \& Daghir, S. (2010). Investigating the relationship between learner's gender, proficiency and language learning strategies: The case of EFL Iraqi learners. Journal of the College of Arts, 53, 32-56.

[2] Ahmadi, A., \& Mahmoodi, S. (2012). Language learning strategy use and instruction for the Iranian junior high school EFL learners. $R A L S, 3(2), 107-134$.

[3] Anderson, N. (2005). L2 strategy research. In E. Hinkel (Ed.), handbook of research in second language teaching and learning (pp.757-772). Mahewah, NJ: Lawrence Erlbaum Associates.

[4] Aslan, O. (2009). The role of gender and language learning strategies in learning English. (M.A. Thesis), Turkish: Middle East Technical University.

[5] Brown, H. (2007). Principles of language learning and teaching $\left(5^{\text {th }}\right.$ Ed.). New York: Pearson Education Inc.

[6] Brumfit, C., \& Johnson, K. (1987). The communicative approach to language teaching. New York: Oxford University Press.

[7] Canale, M., \& Swain, M. (1980). Theoretical bases of communicative approaches to second language teaching and testing. Applied Linguistics, 1(1), 1-47.

[8] Cohen, A. (1996). Second language learning and use strategies: Clarifying the issues. Center for Advanced Research on Language Acquisition, 1-26.

[9] Cornwall, T. (2010). Benefits of teaching grammar: Teacher-2-teacher. Retrieved from: http://www.speechwork.co.th. Retrieved on January, $12^{\text {th }}, 2020$.

[10] Debata, P. (2013). The importance of grammar in English language teaching- A Reassessment. Language in India, 13(5), $482-$ 486.

[11] Dörnyei, Z. (2005). The psychology of the language learner: Individual differences in second language acquisition. Mahwah: Lawrence Eribaum Associates, Inc.

[12] Ehrman, M., Leaver, B., \& Oxford, R. (2003). A brief overview of individual differences in second language learning. System, $31,313-330$.

[13] Ellis, R. (2006). Current issues in the teaching of grammar: An SLA perspective. TESOL Quarterly, 40(1), 83-107.

[14] Fazeli, S. (2011). The Exploring nature of language learning strategies (LLSs) and their relationship with various variables with focus on personality traits in the current studies of second/foreign language learning. Theory and practice in Language Studies, 1(10), 1311-1320.

[15] Ghavamnia, M., Kassaian, Z., \& Dabaghi, A. (2011). The relationship between language learning strategies, Language learning beliefs, motivation, and proficiency: A study of EFL learners in Iran. Journal of Language Teaching and Research, 2(5), 11561161. 
[16] Gimeno, V. (2002). Grammar learning through strategy training: A classroom study on learning conditionals through metacognitive and cognitive strategy training. (Doctoral Dissertation). The University of Valencia, Valencia, Spain.

[17] Goh, C. (2008). Metacognitive instruction for second language listening development: Theory, practice and research implications. Regional Language Centre Journal, 39(2), 188-213.

[18] Goh, C., \& Taib, Y. (2006). Metacognitive instruction in listening for young learners. ELT Journal, 60, $222-232$.

[19] Gurata, A. (2008). The grammar learning strategies employed by Turkish University preparatory school EFL students. (M.A Thesis), Turkish: Bilkent University.

[20] Hinkel, E., \& Fotos, S. (2002). New perspectives on grammar teaching in second language classrooms. Mahwah, N.J.L: Erlbaum Associates.

[21] Hong-Nam, K., \& Leavell, A. (2006). Language learning strategy use of ESL students in an intensive English learning context. System, 34, 399-415.

[22] Krashen, S. (1981). Second language acquisition and second language learning. Oxford: Pergamon Press.

[23] Krashen, S. (1982). Principles and practice in second language acquisition. Oxford: Pergamon Press.

[24] Krashen, S., \& Terrell, T. (1983). The natural approach: Language acquisition in classroom. Oxford: Pergamon Press.

[25] Larsen-Freeman, D. (2001). Grammar. In R. Carter \& D. Nunan (Eds.), The Cambridge guide to teaching English to speakers of other languages (pp. 34-41). New York: Cambridge University Press.

[26] Li, A. (2005). A look at Chinese ESL students use of learning strategies in relation to their English language proficiency, gender and perceived language difficulties- A quantitative study. Supporting Independent English Language Learning in the 21th Century: Proceedings of the Independent Learning Association Conference Inaugural, (pp. 1-24).

[27] Lightbown, P., \& Spada, N. (2006). How languages are learned (3rd ed.). Oxford: Oxford University Press.

[28] Mystkowska-Wiertelak, A. (2008). The use of grammar learning strategies among secondary school students. Faculty of Pedagogy and Fine Arts Press, (pp.139-148). Adam Mickiewicz University

[29] Nassaji, H., \& Fotos, S. (2011). Teaching grammar in second language classrooms: Integrating form-focused instruction in communicative context. New York: Routledge Press.

[30] Neuman, W. (2007). Basics of social research: Qualitative and quantitative approaches (2nd ed.). New York: Pearson Education, Inc.

[31] Nisbet, D., Tindall, E., \& Arroyo, A. (2005). Language learning strategies and English proficiency of Chinese University students. Foreign Language Annals, 38(1), 100-107.

[32] Oller, J., \& Perkins, K. (Eds.) (1978). Language in education: Testing the tests. Rowley: Newbury House.

[33] O’Malley, J., \& Chamot, U. (1990). Learning strategies in second language acquisition. Cambridge: Cambridge University Press.

[34] Oxford, R. (1990). Language learning strategies: What every teacher should know. New York. NY: Newbury House.

[35] Oxford, R. (2003). Language learning styles and strategies: An overview. GALA, 1-25.

[36] Ozmen, D., \& Gulleroglu, H. (2013). Determining language learning strategies used by the students at faculty of educational sciences based on some variables. Education and Sciences, 38(169), 30-40.

[37] Pagcaliwagan, S. B. (2016). Cooperative learning strategy: Effects on students' performance in grammar. European Journal of English Language, Linguistics and Literature, 3(1), 40-49.

[38] Paterson, P., \& Rosbottom, J. (1995). Learning style and learning strategies in a multimedia environment. Association of Learning Technology Journal, 3(1), 12-21.

[39] Pawlak, M. (2009). Grammar learning strategies and language attainment: Seeking a relationship. Research in Language, 7, 4360.

[40] Pontarolo, L. (2013). The role of grammar in EFL instruction: A study on secondary school students and teachers. (Unpublished Doctoral Dissertation), Italy: University of Padova.

[41] Radwan, A. (2011). Effects of L2 proficiency and gender on choice of language learning strategies by university students majoring in English. Asian EFL Journal, 13(1), 115-163.

[42] Rahimi, M., Riazi, A., \& Saif, S. (2008). An investigation in to the factors affecting the use of language learning strategies by Persian EFL learners. CJAL, 11(2), 31-60.

[43] Rama, J., \& Agullo, G. (2012). The role of grammar teaching: From communicative approaches to the common European framework of reference for languages. OUP. United Kingdom.

[44] Richards, J., \& Rodgers, T. (2001). Approaches and methods in language teaching ( ${ }^{\text {nd }}$ ed.). Cambridge: Cambridge University Press.

[45] Rubin, J. (1975). What the good language learners can teach us. TESOL Quarterly, 9(1), 41-51.

[46] Salahshour, F., Sharifi, M., \& Salahshour, N. (2013). The relationship between language learning strategy use, language proficiency level and learners gender. Procedia -Social and Behavioral Sciences, 70, 634-643.

[47] Saricoban, A. (2005). Learner preferences in the use of strategies in learning grammar. Atatürk ÜniversitesiSosyalBilimlerEnstitüsüDergisi, 5(1), 319-330.

[48] Schmidt, R. (1990). The role of consciousness in second language learning. Applied Linguistics, 11(2), 129-158.

[49] Tam, C. (2013). A study on language learning strategies (LLSs) of university students in Hong Kong. Taiwan Journal of Linguistics, 11(2), 1-42.

[50] Temesgen, M. (2013). Exploring English grammar skills learning strategies used by university EFL students: Jimma University in focus. (Unpublished Doctoral Dissertation), Addis Ababa: Addis Ababa University.

[51] Wahyuni, S. (2013). L2 speaking strategies employed by Indonesian EFL Tertiary students across proficiency and gender. (Doctoral Dissertation), Australia: University of Canberra.

[52] Wen, Q. F., \& Wang, L. F. (2004). A twenty years' study on English language learning strategies in China. Foreign Language Literature, 1, 39-45.

[53] Yalcin, F. (2005). An analysis of the relationship between the use of grammar learning strategies and student achievement at English preparatory classes. Journal of Language and Linguistic Studies, 1(2), 155-169. 
[54] Zeynali, S. (2012). Exploring the gender effect on EFL learners' learning strategies. Theory and Practice in Language Studies, 2(8), 1614-1620.

[55] Zhang, J. (2009). Necessity of grammar teaching. International Education Studies, 2(2), 184-187.

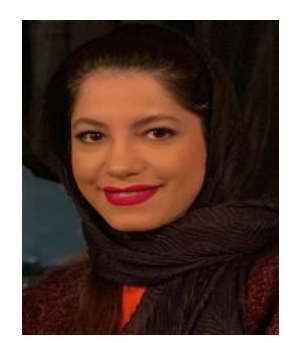

Fereshteh Azizmohammadi is a Ph.D. candidate in Teaching English as a foreign language. She is pursuing her Ph.D. at Ayatollah Amoli branch, Islamic Azad University, Amol, Iran. She is interested in language learning strategy, critical thinking, and dialogic pedagogy. Currently, she is teaching EGP and ESP in different private English language institutes.

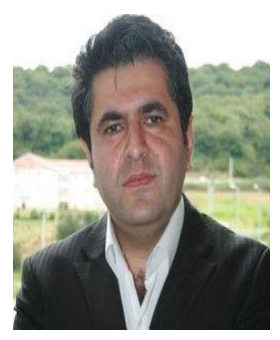

Hamed Barjesteh is an assistant professor of English language at Ayatollah Amoli Branch, Islamic Azad University, Amol, Iran. He serves as the head of English Language department, an editor and a reviewer for various journals and conferences. His research interests lies in the field of critical language pedagogy, thinking skills in language learning, Critical Language testing, dynamic assessment, and corrective feedback. 